\title{
Anatomy of a Severe Dust Storm in the Middle East: Impacts on Aerosol Optical Properties and Radiation Budget
}

\author{
Christos Fountoukis $^{1^{*}}$, Harshvardhan Harshvardhan ${ }^{2}$, Ivan Gladich ${ }^{1}$, Luis Ackermann ${ }^{1 \dagger}$, \\ Mohammed A. Ayoub ${ }^{1}$ \\ ${ }^{1}$ Qatar Environment and Energy Research Institute, Hamad Bin Khalifa University, Qatar Foundation, Doha, Qatar \\ ${ }^{2}$ Purdue University, West Lafayette, IN, USA
}

\begin{abstract}
Particulate matter levels in large urban environments of the Middle East are affected by both anthropogenic and natural sources including frequent dust events which result in considerably enhanced aerosol concentrations with significant human health concerns. In this work, an integrated analysis is conducted of one of the most severe dust storms of the last 20 years in the Middle East. Using WRF-Chem simulations along with satellite data, particulate matter surface measurements and AERONET observations, we study the impact of this event on optical properties and surface radiation. At the peak of the dust storm in Doha, Qatar, both the surface data and the model predictions showed PM $_{10}$ concentrations in excess of $7,000 \mu \mathrm{g} \mathrm{m}^{-3}$. A 2-week simulation over the whole peninsula revealed the extent of the event and showed that the model was able to capture the temporal and spatial evolution of the dust storm and the associated variations in aerosol optical properties. The simulations and remotely sensed measurements showed good correlation for the aerosol optical depth parameter, which reached a value of 3.0 on 2 April 2015 in the region. In agreement with satellite-derived estimates, the model predicted a significant storm-induced reduction in the shortwave radiation (150 to $300 \mathrm{~W} \mathrm{~m}^{-2}$ ) reaching the eastern Arabian Peninsula, and the Gulf waters, and a considerable drop in the precipitable water (by a factor of 6) between 01 and 03 of April 2015. The domain-integrated maximum daily dust deposition rate that the model predicted was $27.5 \mathrm{Tg}^{2} \mathrm{day}^{-1}$ mostly over the eastern part of Arabian Peninsula. The performance of the model is encouraging for further use in operational forecasting of dust storms in the region.
\end{abstract}

Keywords: AOD; shortwave radiation; aerosols; WRF-Chem; Arabian Desert

\section{INTRODUCTION}

An important contributor to atmospheric composition in arid and semi-arid regions is mineral dust generated by wind erosion. Atmospheric dust particles in high concentrations have multiple effects on human health, climate and the ecosystem. Dust particles are linked to cardiovascular, respiratory and allergic diseases (Bennett et al., 2006; Bennion et al., 2007; Morman and Plumlee, 2014). Severe dust storms can cause traffic and aircraft transportation problems as well as damage crops and soil fertility. Increased dust levels can also affect solar resources for renewable energy applications by interacting (scattering and absorbing) with solar radiation (Li et al., 2017; Fountoukis et al., 2018a, b). Deposition of

\footnotetext{
${ }^{\dagger}$ Now at Monash University, Melbourne, Australia.

* Corresponding author.

Tel.: +974-44540876; Fax: +974-44541528

E-mail address: cfountoukis@hbku.edu.qa
}

dust and sand to the sea affects the nutrient balance of ocean waters and perturbs the fertilization of phytoplankton (Johnson et al., 2011; Prakash et al., 2015).

The Middle East and North Africa region include approximately half of the global dust emissions, accounting for 500-1000 $\mathrm{Tg} \mathrm{yr}^{-1}$ (Prospero et al., 2002; Zender et al., 2004) although large uncertainties in these estimations still remain. The Sahara, the world's largest dust source area, can cause large amounts of dust to be transported over hundreds or even thousands of kilometers affecting air quality, human health and climate with global implications (Shao et al., 2011). In the Arabian Peninsula dust events frequently occur throughout the year causing increased levels of $\mathrm{PM}_{10}$ and $\mathrm{PM}_{2.5}$ (particulate matter with a diameter less than 10 and 2.5 microns, respectively; Pease et al., 1998; Tsiouri et al., 2015; Saraga et al., 2017). However, few measurement campaigns have been conducted and continuous particulate matter observations are very scarce in this region.

Certain areas highlighted as major dust sources in the Middle East have been identified in several previous modeling studies (Pease et al., 1998; Prospero et al., 2002; Rezazadeh et al., 2013; Fountoukis et al., 2016). Kalenderski et al. 
(2013) studied a typical winter-time (January 2009) dust event using the Weather Research and Forecasting model with Chemistry (WRF-Chem) and showed that dust aerosols caused a significant change in energy and nutrient balances of the Red Sea. Prakash et al. (2015) quantified the impact of a dust episode on the terrestrial (Arabian Peninsula) and oceanic (Red Sea) environment over a 4-day period of March 2012 using WRF-Chem simulations along with AERONET (Aerosol Robotic Network) aerosol optical depth (AOD) observations. They identified the Tigris and Euphrates River Valleys as the major dust source areas injecting more than $300 \mu \mathrm{g} \mathrm{m}^{-2} \mathrm{~s}$ of dust into the atmosphere during this episode. Fountoukis et al. (2016) evaluated WRF-Chem $\mathrm{PM}_{10}$ predictions using two different dust emission schemes over the Middle East during a summer time period of 2015. Anisimov et al. (2017) used the Community Land Model version 4 (CLM4) in high resolution $(1 \mathrm{~km})$ over the narrow Arabian Red Sea coastal plain to estimate the first fine-scale spatial and temporal (2009-2011) distribution of dust emissions in the area. Kontos et al. (2018) simulated dust emissions in the central part of the Middle East with a $6 \mathrm{~km}$ horizontal grid resolution during April-June of 2015 focusing on assessing the sensitivity of dust modules in various components of the relevant dust parameterization.

Although dust storms originating from the North Africa region have been thoroughly investigated (Laurent et al., $2008 ; 2010)$, severe dust events within the region of the Arabian Peninsula have received less attention even though they affect large population centers in the region (Roshan et al., 2019) as well as impact the marine ecosystem of the Arabian Sea, Red Sea and Gulf waters. Furthermore, within the Arabian Desert the eastern sector of the Peninsula has not been studied much compared to the western part (Kalenderski et al., 2013; Prakash et al., 2015; Anisimov et al., 2017) even though previous studies have shown that the eastern part receives more frequent dust outbreaks (Prospero et al., 2002; Goodie and Middleton, 2006; Shalaby et al., 2015; Roshan et al., 2019). In this work we combine WRFChem simulations along with satellite data and continuous particulate matter measurements from a monitoring station in Qatar to analyze the anatomy of one of the most severe dust storms that occurred during the last 20 years in the Middle East and largely affected the eastern part of the Arabian Peninsula (Tsiouri et al., 2015; Beegum et al., 2018). The impact of this typical yet severe spring-time (31 March4 April 2015) dust episode on aerosol optical properties and radiation budget over the greater region is analyzed.

\section{METHODS}

\section{Meteorology-chemistry Model Application}

The three dimensional chemical transport model WRFChem (version 3.9.1) was applied over the Middle East to simulate emissions of atmospheric constituents (gases and aerosol particles), their transport and physicochemical transformations (Fast et al., 2006). WRF-Chem was employed on a two-way nesting configuration with three domains, at different grid resolutions, communicating with each other while information of species concentrations propagates into and out of all computational domains during the model integration (Fig. 1).

A $50 \mathrm{~km} \times 50 \mathrm{~km}$ grid resolution is used for the parent domain while the intermediate nested domain used a $10 \mathrm{~km}$ $\times 10 \mathrm{~km}$ resolution focusing on the Arabian Desert. The third domain was configured over the region of Qatar where our continuous air quality monitoring station is located and was resolved at $2 \mathrm{~km} \times 2 \mathrm{~km}$. This grid nesting configuration of WRF-Chem helps cover a large area (the whole peninsula), as the dust episode was extensive, but at the same time provides fine resolution in selected areas to address smaller scale features and better compare with observations. Twentyeight vertical layers were used in all three computational domains extending from the surface to approximately $20 \mathrm{~km}$. WRF-Chem simulations were performed on a lambert map projection and covered a twenty-day period (22 March-11 April, 2015) for which the first week was considered spinup time and was excluded from the analysis. Static geographical data along with dynamic meteorological data generated by the Global Forecast System (GFS) were used to initialize WRF (https://www.ncdc.noaa.gov/data-access). All simulations are retrospective (historical), not forecasts. Boundary conditions for the outermost domain are taken from idealized profiles specified in the chemistry routines. For all inner domains, boundary conditions are taken from their respective parent domains. For the sea surface temperature (SST) input data we use daily averaged data since we run WRF-Chem for more than a week. We make use of the RTG_SST analysis NOAA product (https://polar.ncep.noaa. gov/sst/ophi/) which provides SST data on a $0.25 \times 0.25$ grid resolution.

The physics part of all WRF-Chem simulations includes the Lin microphysics scheme (Chen and Sun, 2002), the revised MM5 Monin-Obukhov surface layer scheme, the Grell 3D cumulus parameterization (Grell and Devenyi, 2002), the Rapid Radiative Transfer Model longwave (Mlawer et al., 1997) and shortwave radiation schemes (Iacono et al., 2008), the 5-layer thermal diffusion Land Surface Model and the Yonsei University boundary layer scheme (Hong et al., 2006) which has been shown to well represent the vertical profiles of meteorological parameters in the Middle East (Fountoukis et al., 2018c). The RACM (Regional Atmospheric Chemistry Mechanism) chemistry scheme is used (Stockwell et al., 1997; Geiger et al., 2003) in all simulations coupled with the Georgia Institute of Technology-Goddard Global Ozone Chemistry Aerosol Radiation and Transport (GOCART) aerosol module (Ginoux et al., 2001).

Windblown dust emissions are calculated in the model using the US Air Force Weather Agency (AFWA) dust parameterization. The AFWA module includes the MB95 (Marticorena and Bergametti, 1995) dust emission scheme that uses airborne dust size distributions of Kok (2011) and calculates dust fluxes via:

$$
F=a E c \frac{\rho_{\alpha}}{h} u_{*}^{3}\left(1+\frac{u_{*_{t}}}{u_{*}}\right)\left(1-\frac{u_{*_{t}}^{2}}{u_{*}^{2}}\right)
$$

where $u *$ is the friction velocity, $u * t$ is the threshold friction 


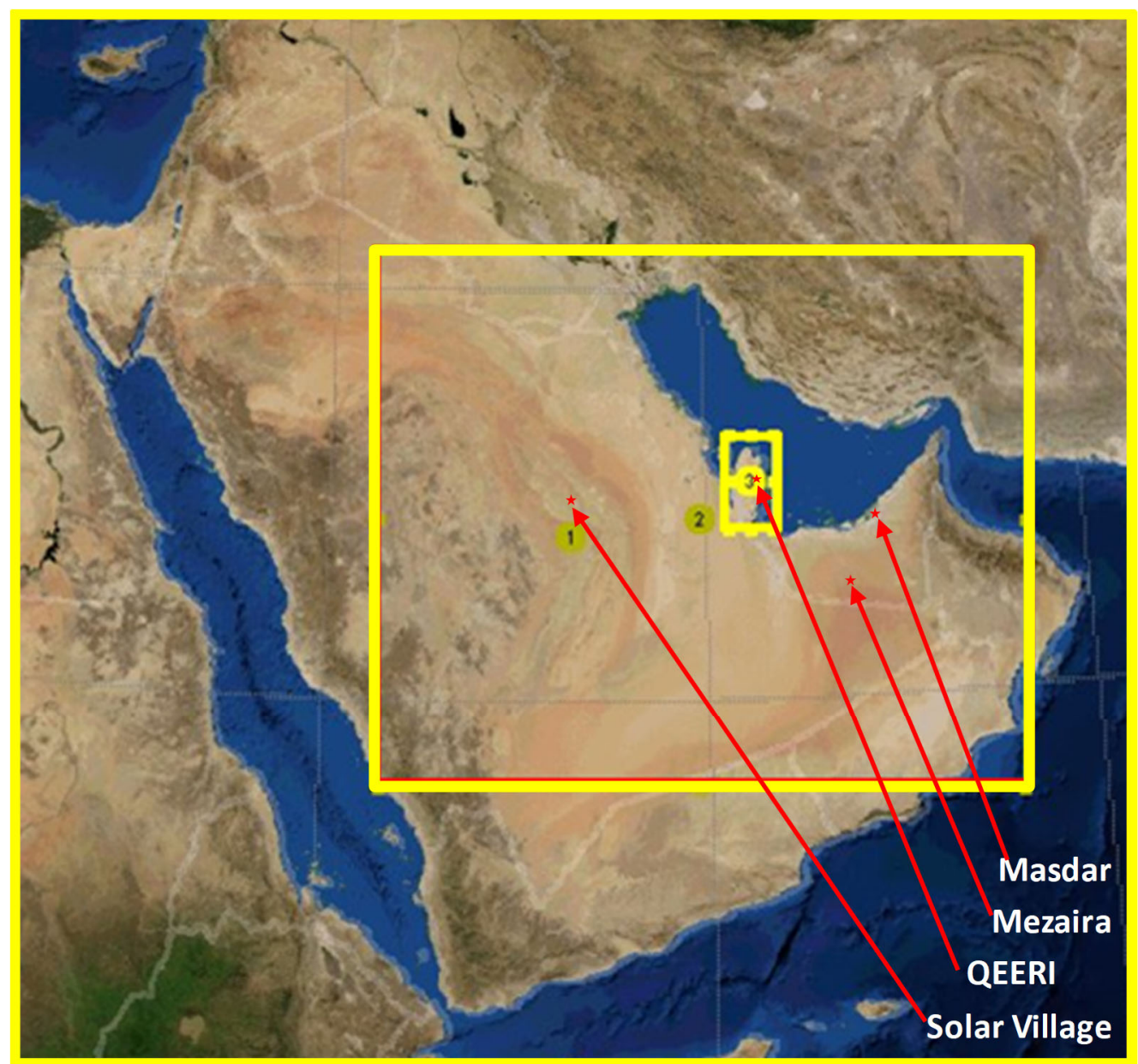

Fig. 1. Configuration of three WRF-Chem modeling domains at different grid resolutions over the Middle East region; (1): $50 \mathrm{~km} \times 50 \mathrm{~km}\left(10.3^{\circ}-36.1^{\circ}\right.$ latitude, $29.5^{\circ}-63.3^{\circ}$ longitude), (2): $10 \mathrm{~km} \times 10 \mathrm{~km}\left(17.2^{\circ}-30.6^{\circ}\right.$ latitude, $40.6^{\circ}-$ $58.8^{\circ}$ longitude) and (3): $2 \mathrm{~km} \times 2 \mathrm{~km}\left(24.1^{\circ}-26.4^{\circ}\right.$ latitude, $50.6^{\circ}-51.9^{\circ}$ longitude). The numbers 1,2 and 3 in the figure indicate the center point of each of the three computational domains, respectively. Also shown the locations of the AERONET stations and the QEERI monitoring site.

velocity, $\rho_{\alpha}$ is the air density, $g$ is the gravitational acceleration, $c$ is an empirical proportionality constant, $E$ is the erodibility factor (Ginoux et al., 2001) and $\alpha$ is the sandblasting efficiency. Anthropogenic emissions were extracted from the REanalysis of the TROpospheric (RETRO) chemical composition (http://retro.enes.org) database and the Emission Database for Global Atmospheric Research (EDGAR) (http://www.mnp.nl/edgar/introduction). EDGAR provides information on the evolution of the emission inventories over time for all world countries in $0.1^{\circ} \times 0.1^{\circ}$ grid maps representing the emission sources while RETRO is at $0.5^{\circ} \times$ $0.5^{\circ}$ resolution. Based on the EDGAR-HTAP project (Hemispheric Transport of Air Pollution emissions - version 2; http://www.htap.org/), a global emission dataset is used, that utilizes official or scientific inventories at the national or regional scale, with annual inventories for anthropogenic emissions for black carbon (BC) and organic carbon (OC), particulate matter $\left(\mathrm{PM}_{10}\right.$ and $\left.\mathrm{PM}_{2.5}\right)$, sulfur dioxide $\left(\mathrm{SO}_{2}\right)$, ammonia $\left(\mathrm{NH}_{3}\right)$, nitrogen oxides $\left(\mathrm{NO}_{\mathrm{x}}\right)$, methane $\left(\mathrm{CH}_{4}\right)$, carbon monoxide $(\mathrm{CO})$ and non-methane volatile organic compounds (NMVOCs). Biogenic emissions are computed
(Guenther et al., 1994) using the United States Geological Survey (USGS) land use classification system and the WRF pre-processing system (WPS).

\section{Satellite Data}

In this study we use data from the Moderate Resolution Imaging Spectroradiometer (MODIS). MODIS observes spectral radiance across 36 spectral bands (from $440 \mathrm{~nm}$ to $14,400 \mathrm{~nm}$ ) (Cheng et al., 2012). It was launched by NASA in 1999 on board the Terra satellite and in 2002 on board the Aqua satellite and has its algorithms repeatedly updated by NASA. MODIS provides spatial resolution of $250 \mathrm{~m}, 500 \mathrm{~m}$, and $1 \mathrm{~km} . \mathrm{A} \pm 55^{\circ}$ scanning pattern of the Earth Observing Satellite (EOS) orbit at $705 \mathrm{~km}$ altitude achieves a 2,330 km swath and provides global coverage every 1 to 2 days. The MODIS daily Level-2 (quality and cloud-screened) AOD data are produced at $10 \mathrm{~km} \times 10 \mathrm{~km}$ spatial resolution. To maximize the observation coverage, the study uses AOD retrievals over land and sea derived from the "Dark Target" algorithm (Remer et al., 2008) and the "Deep Blue" algorithm (AOD retrievals at $550 \mathrm{~nm}$ over bright surfaces 
such as deserts) (Hsu et al., 2004). For the period of this study (April 2015) MODIS Collection 5 (Levy et al., 2013) is used. The MODIS uncertainty is $\pm(0.03+0.05 \times$ AOD $)$ over ocean and $\pm((0.05+0.20 \times$ AOD) over land (Kaufman et al., 1997; Tanre et al., 1997; Ruiz-Arias et al., 2013).

\section{Ground Observations}

Surface observations were made at the Qatar Environment and Energy Research Institute (QEERI) in Education City, Doha $\left(25.218^{\circ} \mathrm{N}, 51.433^{\circ} \mathrm{E}\right)$, a site that is representative of urban background air quality. The station is equipped with a PM analyzer (MP101 M) suited with an impact plate sampling head (U.S. EPA PM10). Data quality assessment is performed routinely, following the standardized data validation methodology of the U.S. EPA (U.S. EPA, 2000). The instrument operates uninterruptedly, which allows for a continuous determination of aerosol concentration variability in Doha, Qatar. Ambient $\mathrm{PM}_{10}$ concentrations were measured continuously during the dust storm period that is analyzed in this study. The air monitoring station was also equipped with a Thermo-hygrometer (DMA867-875) for continuous measurements (every $1 \mathrm{~min}$ ) of ambient relative humidity and temperature as well as an Anemometer (DNA827) for the wind speed and wind direction. Additionally, in this work we make use of the AOD data measured by the groundbased sky radiometers and sun photometers of the Aerosol Robotic Network (AERONET, Holben et al., 1998). In the Arabian Peninsula there are three AERONET stations that we found available data for the period of this study; in Saudi
Arabia (Solar Village station: latitude $=24.91$, longitude $=$ 46.4) and in United Arab Emirates (Mezaira station: latitude $=23.1$, longitude $=53.75$, and Masdar Institute station: latitude $=24.44$, longitude $=54.62$ ). AERONET provides columnintegrated aerosol optical properties at 8 different wavelengths $(340,380,440,500,675,870,940$, and $1020 \mathrm{~nm})$.

\section{RESULTS AND DISCUSSION}

\section{Meteorological Characteristics of the Dust Event}

A massive sandstorm, also known as Haboob (from the Arabic word meaning blowing wind and dust), evolved over the Middle East beginning on the $31^{\text {st }}$ of March, 2015 and lasted through the $4^{\text {th }}$ of April 2015. The sandstorm was associated with a low pressure system, with strong winds and counterclockwise circulation around the low. Fig. 2 shows the modeled spatial distribution of day-to-day variation of sea level pressure from 30 March to 4 April 2015 at 00:00 UTC over the modeling domain of the Middle East.

On 31 of March the sea level pressure shows that the low pressure system gained momentum over southern Iraq and moved southeastward across the eastern Arabian Peninsula. The system generated strong winds which caused high amounts of desert dust to be lifted into the atmosphere. Based on the observed data, the leading edge of the storm passed over QEERI's ground monitoring station in Doha, Qatar at 9:30 p.m. on April $1^{\text {st }}$ reducing visibility in the city and sharply increasing ground level particulate matter concentrations. The tail-end of the system passed over Doha
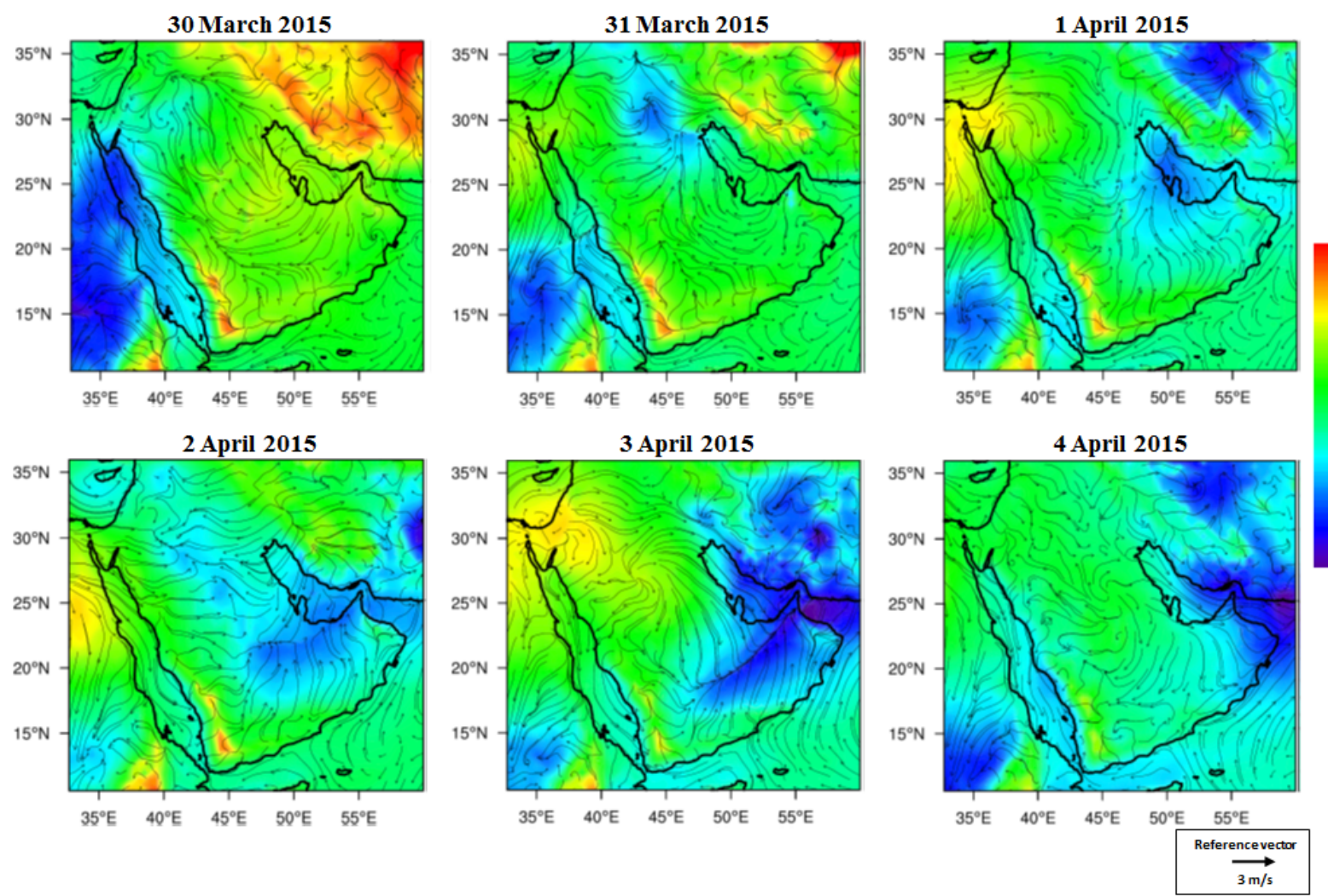

Fig. 2. Spatial distribution of sea level pressure simulated by WRF-Chem over the Middle East during 30 March-4 April 2015 at 00:00 UTC time. 
around 2:30 p.m. on the $2^{\text {nd }}$ of April leaving strong winds in its wake. The system finally weakened as it continued its track over the south east of the Arabian Peninsula on the $3^{\text {rd }}$ and $4^{\text {th }}$ of April 2015. The sea level pressure increased again causing a decrease in both wind speed and ambient dust concentrations.

\section{Comparison of Model Predictions with Ground Measurement Data}

The QEERI Air Quality Monitoring Station measured meteorological and air quality parameters during the passage of the storm. As the Haboob front reached the station, a sharp increase in wind speed from $1.3-10 \mathrm{~m} \mathrm{~s}^{-1}$ was recorded. This was followed by two peaks in $\mathrm{PM}_{10}$ and $\mathrm{PM}_{2.5}$ at 2:30 a.m. and 6:30 a.m. on the morning of the $2^{\text {nd }}$ of April. The peninsula of Qatar includes a mostly flat terrain and barren desert covered with sand dunes and salt flats in the south and south-west of the country with fine-grained dust covering the east part. The average wind speed dropped to about $21 \mathrm{~km} \mathrm{~h}^{-1}$ in between the two peaks. The bimodal nature of the PM measurements is a classic representation of a strong low pressure system. Fig. 3 shows a comparison of hourly $\mathrm{PM}_{10}$ concentrations predicted by WRF-Chem for the location of the station with the observed data.

Particulate matter concentrations peaked with the leading edge of the system, dropped as the center of circulation passed over Doha and increased again (with higher concentrations) as the tail end passed over the city. At its peak, $\mathrm{PM}_{10}$ concentrations were greater than $10 \mathrm{mg} \mathrm{m}^{-3}$. These are significantly high concentrations with potential human health impacts and justify the State's decision to close schools on that day. WRF-Chem was able to successfully predict the onset of the storm as well as the two smaller dust events observed during April 5 and 6. Overall, during the two-week simulation period the performance of the model in predicting $\mathrm{PM}_{10}$ concentrations was encouraging. Excluding the day of the peak, the model reproduced hourly $\mathrm{PM}_{10}$ concentrations with a fractional error $\left(\right.$ FERROR $=2 / n \sum_{i=1}^{n}\left|P_{i}-O_{i}\right| /\left(P_{i}+O_{i}\right)$, where $P_{i}$ represents the model predicted value for data point $i, O_{i}$ is the corresponding observed value and $n$ is the total number of data points) of 0.5 and a bias of 0.19 . This is a challenging comparison considering the high time-resolution of the measured and modeled data. At the peak of the dust storm, the model predicted $\mathrm{PM}_{10}$ concentrations in excess of $7,000 \mu \mathrm{g} \mathrm{m}^{-3}$ while the measured $\mathrm{PM}_{10}$ values were much higher (although the instrument's upper calibration limit is $10 \mathrm{mg} \mathrm{m}^{-3}$ ). The severity of this dust storm is evident considering that studies of similar dust storms in the region have reported a maximum of approximately $2,000 \mu \mathrm{g} \mathrm{m}^{-3}$ of $\mathrm{PM}_{10}$ concentrations (Kalenderski et al., 2013; Prakash et al., 2015).

In Fig. 4, hourly AOD simulated by WRF-Chem is compared against co-located observations of AOD from three AERONET stations in the region.

Only a limited number of AERONET observations were available during this dust outbreak. Any available instantaneous measurements from the three sites were averaged hourly for comparison with the hourly simulated AOD data of WRF-Chem. In agreement with observations the model predicted a significant increase in AOD at the location of the Masdar Institute site on the $2^{\text {nd }}$ of April. The Mezaira station did not report any measurements on 2 April as the dust completely blocked out the Sun and the aerosol optical depth was too thick. However, on $1^{\text {st }}$ and $3^{\text {rd }}$ of April the model well reproduced the relatively low AOD values at this site. Both the observed and the simulated AOD at Solar Village did not show any strong sign of the dust storm passage. It should be noted that, unlike previous similar studies, a storm-following variable value is being used here for the $c$ constant of Eq. (1). In previous studies a constant value (0.4-0.6) was suggested as representative for this region at any given time and location (Zhao et al., 2010; Kalenderski et al., 2013; Su and Fung, 2015). However, based on comparison with observations (both $\mathrm{PM}_{10}$ and AOD measurements), a different approach is followed in the present study. A value of 1 is utilized for the specific time and computational cells that are largely influenced by the dust outbreak and a value

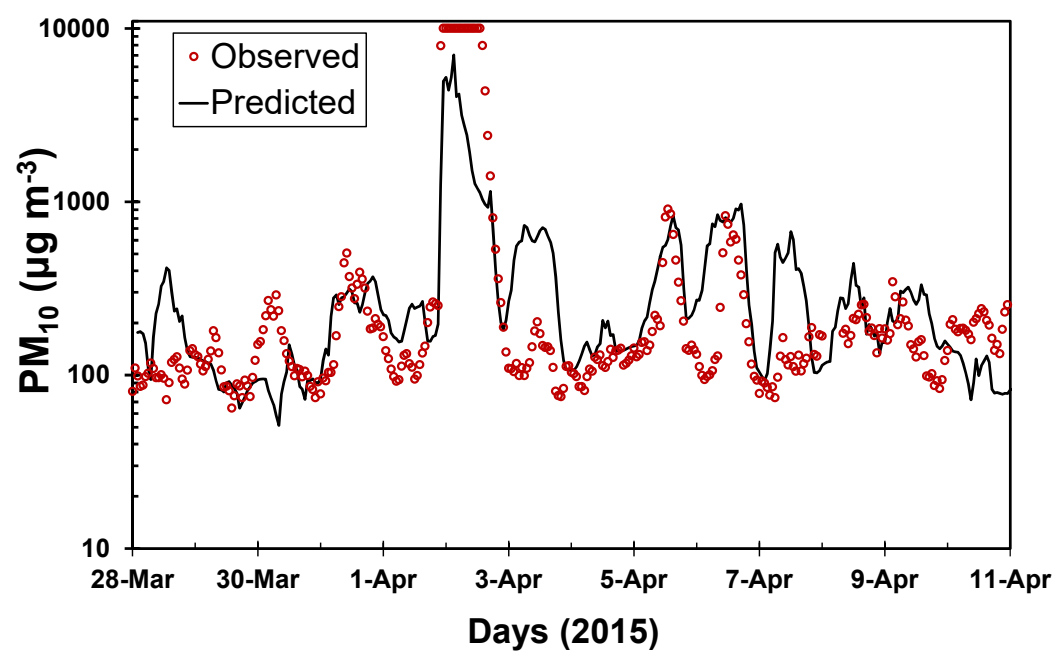

Fig 3. Comparison of simulated (black line) vs. observed (red circles) $\mathrm{PM}_{10}$ concentrations in Doha, Qatar during the dust episodic days. 

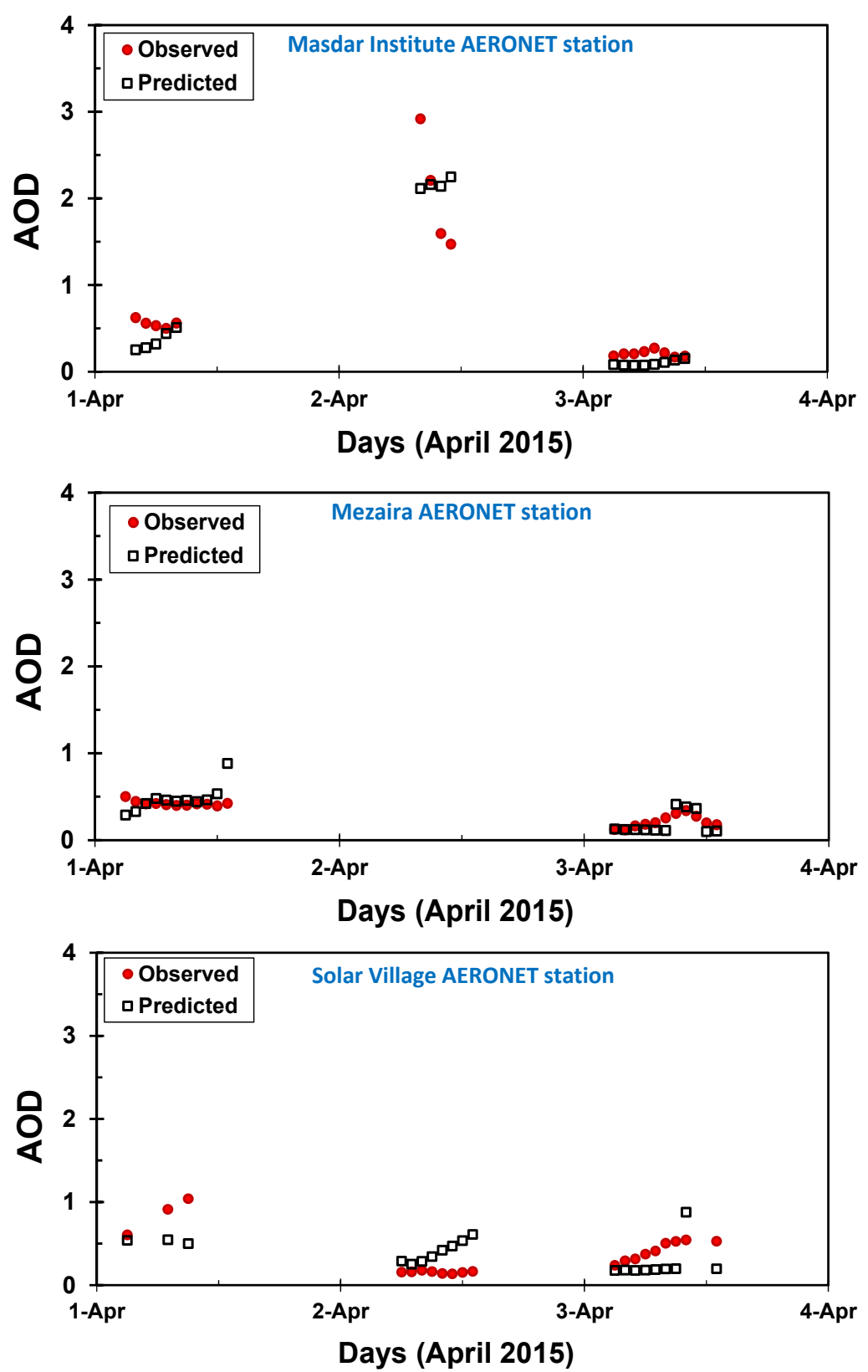

Fig 4. Time series of observed (red circles) and simulated (black squares) AOD at three AERONET sites during 1-4 April 2015.

of 0.2 (Fountoukis et al., 2016) for the rest of the domain and time that is not affected by the dust storm. This approach appears to better predict the intensity of the storm and at the same time not over predict PM levels in desert areas when they are not directly affected by the storm. For example, in the Masdar Institute AERONET site the correlation coefficient between observations and the model for AOD is 0.7 for a constant value of $c=0.2,0.79$ for $c=1$ and 0.92 for a variable $c$. Similar improvement in the model performance is seen in the Mezaira and Solar Village sites as well as with regard to $\mathrm{PM}_{10}$ concentrations in Doha's monitoring station. A severe dust storm is identified in a computational cell if its 24-h mean $\mathrm{PM}_{10}$ concentrations are over $1,000 \mu \mathrm{g} \mathrm{m}^{-3}$ (Tsiouri et al., 2015; Saraga et al., 2017).

\section{Influence of Dust Storm on Optical Properties}

Fig. 5 shows the average spatial distribution of simulated AOD $(600 \mathrm{~nm})$ over the Arabian Peninsula and the Gulf sea during three days of low dust levels and a 3-day period of high concentrations of dust during the dust storm, as well as their average percentage difference. On average, the model predicted an increase of a factor of 2 in the AOD over the Eastern Arabian Peninsula as a result of this dust outbreak. The highest AOD values during 31 March-2 April 2015 are predicted over Southern Iraq, North-Eastern Saudi Arabia and Qatar. AOD values averaged over the modeling domain (domain 2) during the low dust period are predicted as 0.43 \pm 0.22 and the corresponding average values during the high dust period were $0.77 \pm 0.45$ while, locally, an increase of 
up to a factor of 4 was predicted. Over the Arabian Gulf, the model predicts an increase in AOD of more than $100 \%$ on average. This is consistent with Banks et al. (2017) and Roshan et al. (2019) who showed that the Arabian Gulf region receives more prolonged and intense dust storms than the western side of the Arabian Peninsula and the Red Sea. These AOD values highlight the intensity of this dust event compared to previous studies in the region that showed an AOD maximum value of approximately 0.5 (Kalenderski et al., 2013).

Although the dust storm was felt strongly in Qatar on 2 April, it was an extensive event and an integrated analysis of its impact on optical and radiative properties should look at the whole peninsula and go through the entire life cycle of the storm day by day. Fig. 6 shows the spatial distributions of AOD simulated by WRF-Chem and retrieved from MODIS daily during a 3-hour period (average of 07:30-10:30 UTC) from 30 March to 4 April 2015.

MODIS retrievals consist of two readings (1030 and 1330 local time on Terra and Aqua, respectively) at 1 degree resolution using the Model for Atmospheric Transport and Chemistry (MATCH) (Collins et al., 2001). The same averaging time has been used for the WRF-Chem figure panels while the grid resolution of the WRF-Chem modeling domain is set at $50 \times 50 \mathrm{~km}^{2}$. Overall, the model was able to capture the temporal and spatial evolution of the dust storm and the associated variations in aerosol optical properties, which provides confidence for using the model to understand the impact of this dust event on the radiation budget. Both WRF-Chem and MODIS show similar AOD distributions in the region with the exception of the morning of April $1^{\text {st }}$ when the model over predicts the AOD values. In agreement with the findings in Fig. 4, Fig. 6 depicts that both the WRFChem and MODIS retrievals show that the Solar Village AERONET site escaped the peak of the dust plume. This highlights the ability of the model to predict the geographical boundary between low dust and high dust during the outbreak. A considerable drop in the precipitable water (from approximately $3 \mathrm{~cm}$ to $0.5 \mathrm{~cm}$ ) was also observed by the satellite-retrieved data over the same region on April $2^{\text {nd }}$ and $3^{\text {rd }}$ (Fig. S1). This sharp drop in moisture after the frontal passage is corroborated by both WRF-Chem and AERONET observations (not shown).

\section{Influence of Dust Storm on Radiation Budget}

In this section we investigate the dust-induced perturbation of shortwave radiation flux at the surface. WRF-Chem
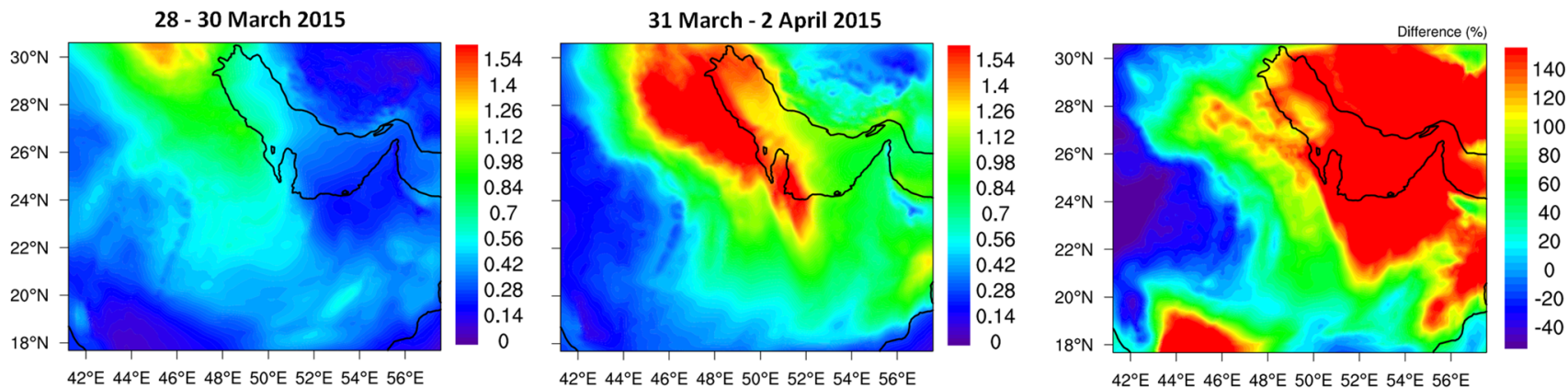

Fig. 5. Spatial distribution of AOD simulated by WRF-Chem over the Arabian Peninsula and the Gulf Sea during a low (2830 March 2015) and a high dust period (31 March - 2 April 2015) including their percentage change.
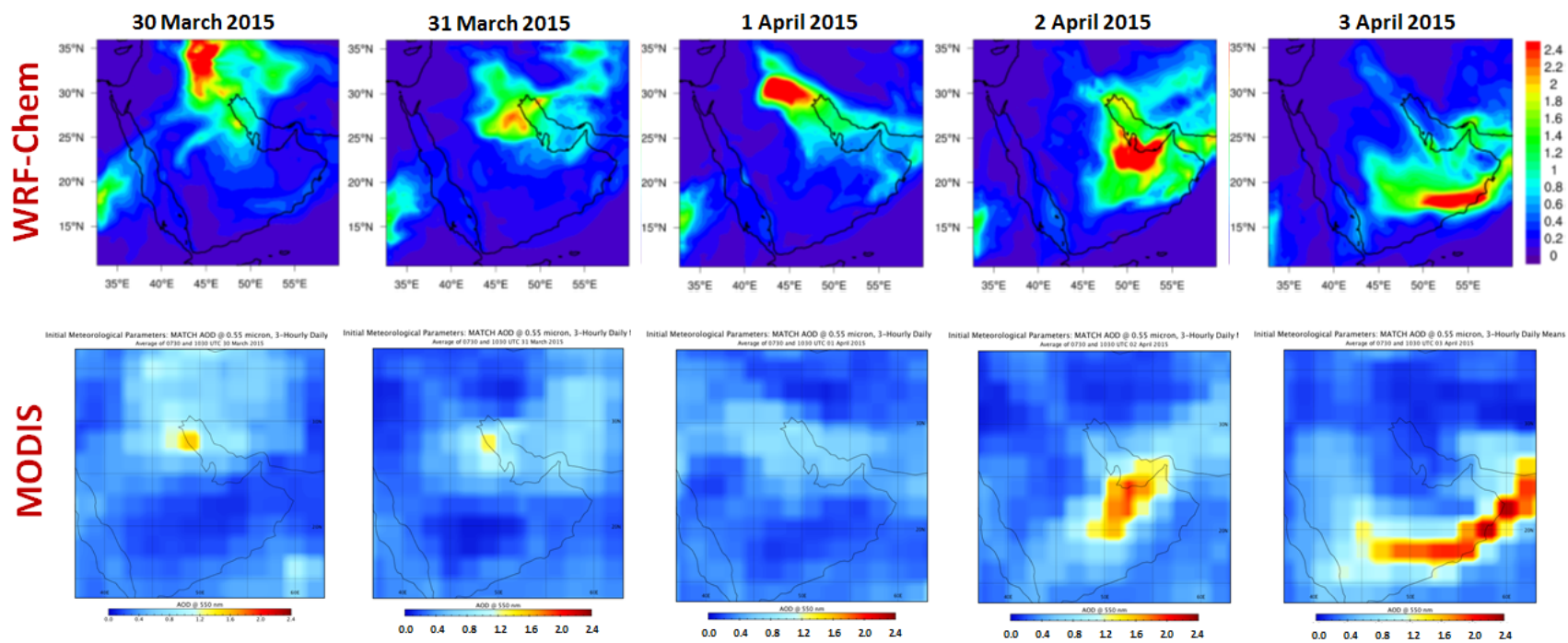

Fig. 6. Spatial distribution of AOD over the Arabian Peninsula and the Gulf Sea simulated by WRF-Chem and retrieved by MODIS aboard Aqua and Terra during a 3-hour period (average of 07:30-10:30 UTC) between 30 March and 4 April 2015. 
includes the option to permit interactions of aerosols with radiation and model dynamics. All model results discussed so far (including Figs. 2-6) are from simulations that include the aerosol-radiation feedbacks. In this section, two WRF-Chem simulations were performed; one with and one without the aerosol radiative effect and their difference, the aerosol forcing, is shown in Fig. 7 as simulated by WRF-Chem and also retrieved by CERES at 0930 UTC on 1, 2 and 3 April 2015. The CERES (Clouds and the Earth's Radiant Energy System; Rutan et al., 2015) synoptic product is used for comparison with WRF-Chem (Fig. 7) which provides $1^{\circ} \times 1^{\circ}$ gridded surface radiant fluxes with and without aerosols. CERES surface downward flux involves a modeling approach that is not suitable for long-term trends but is recommended for comparison with surface sites at a particular time (Kato et al., 2013). The surface fluxes are computed from a radiative transfer model constrained by Terra and Aqua (MODIS), 3-hourly geostationary (GEO) data, and meteorological assimilation data from the Goddard Earth Observing System.

In agreement with the CERES retrievals, WRF-Chem predicts a significant storm-induced reduction in the shortwave radiation reaching the eastern Arabian Peninsula and the Gulf waters that ranges from 150 to $300 \mathrm{~W} \mathrm{~m}^{-2}$ between 01 and 03 of April. This is clearly depicted in Fig. 7 by green, yellow and red color. In Qatar, there was more than $200 \mathrm{~W} \mathrm{~m}^{-2}$ less surface downward flux at 0930 UTC on 2 April because of the aerosol presence. Once more, this shows the severity of this dust storm as the surface flux reduction is approximately 3-5 times higher than the one reported in other similar studies in the region (Kalenderski et al., 2013; Prakash et al., 2015). The sensor temperature in Doha's monitoring station dropped by 18 degrees at about the same time from 01 to 02 April and it remained cool into 03 April. Over the 3-day period of high aerosol concentrations (31 March-2 April 2015) the predicted domain-average dust-induced shortwave perturbation at the surface was $-30 \mathrm{~W} \mathrm{~m}^{-2}$. Over the Gulf Sea the average aerosol radiative effect due to the dust storm was more than $-50 \mathrm{~W} \mathrm{~m}^{-2}$ (Fig. S2). At the top of the atmosphere the average impact over the Gulf Sea is predicted to be noticeably stronger than over the rest of the Arabian Peninsula due to the significantly lower albedo of the sea compared to the desert areas. The simulated longwave (LW) radiative perturbation of dust at the top of the atmosphere is generally small and has a domain-averaged value of $1-2 \mathrm{~W} \mathrm{~m}^{-2}$. At the surface, the dust LW effect warms the surface by trapping LW radiation emitted by the Earth's surface and is predicted to be approximately $10 \mathrm{~W} \mathrm{~m}^{-2}$ on average. The net (SW + LW) radiative perturbation of dust is thus controlled mostly by SW radiative effects and has a cooling effect. This dust episode cooled the atmospheric column over the Arabian Gulf by more than $30 \mathrm{~W} \mathrm{~m}^{-2}$ on average with potential implication for the ecology of the sea.

\section{CONCLUSIONS}

A severe dust storm swept across the Arabian Peninsula in the beginning of April 2015. Outdoor surface concentrations of particulate matter exceeded $10 \mathrm{mg} \mathrm{m}^{-3}$ at Doha, Qatar on
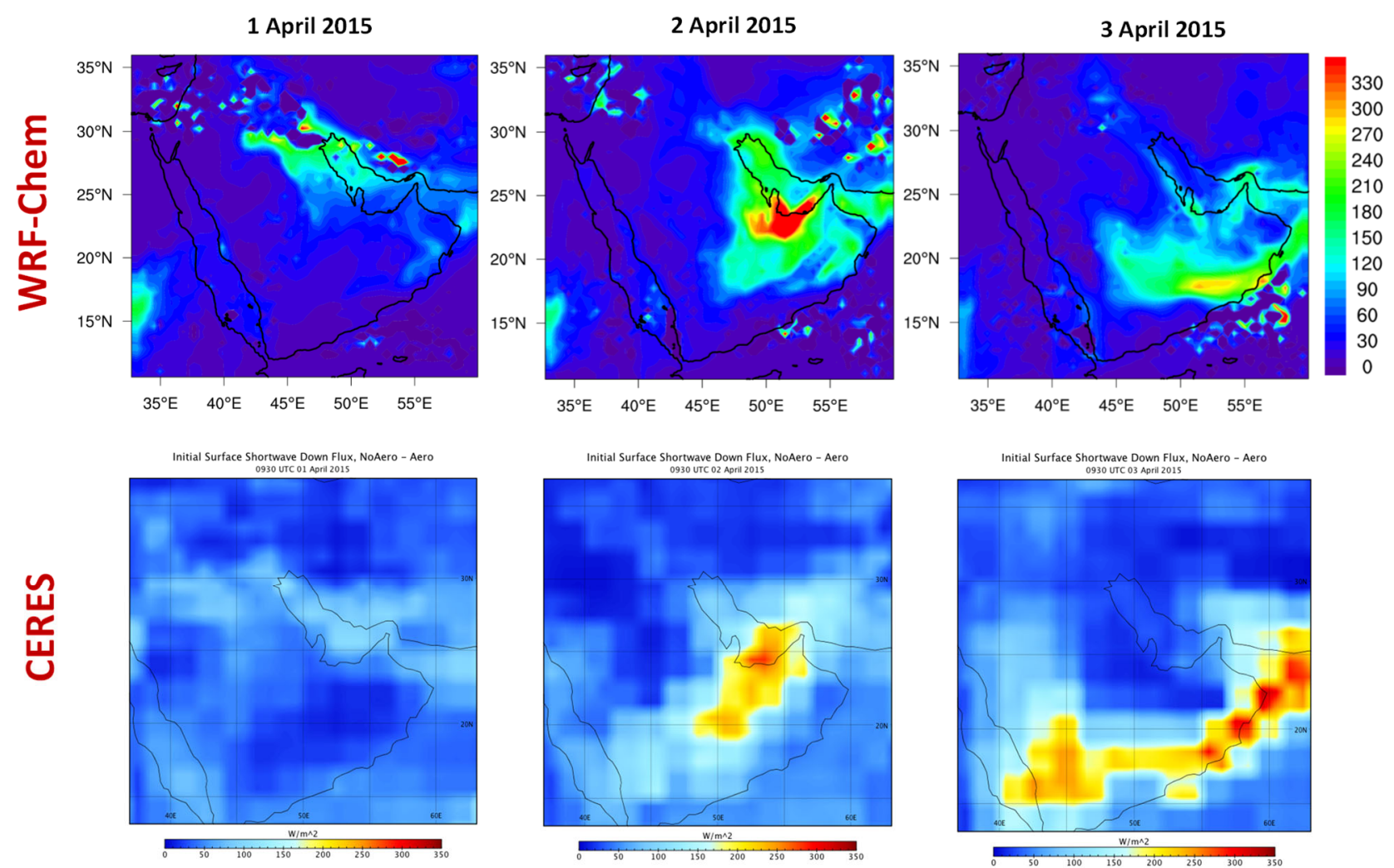

Fig. 7. Spatial distribution of downward shortwave aerosol forcing (in $\mathrm{W} \mathrm{m}^{-2}$ ) at surface as simulated by WRF-Chem and retrieved by CERES at 0930 UTC on 1, 2 and 3 April 2015. 
2 April 2015. This event has been simulated by WRF-Chem and relevant parameters such as particulate matter concentrations, aerosol optical depth, precipitable water, and reduction in downwelling shortwave radiation, have been analyzed and compared with corresponding quantities obtained from satellite instruments as well as ground measurements. WRF-Chem was able to successfully predict the onset, geographical boundaries and duration of the dust event. In Doha, Qatar, the model reproduced hourly $\mathrm{PM}_{10}$ concentrations with a fractional error of 0.5 and a bias of 0.19 throughout the simulation period. The simulations and remotely sensed measurements showed good correlation for the aerosol optical depth parameter which exceeded a value of 3.0 on 2 April in the region. A considerable drop in moisture (by a factor of 6) was observed by the satellite-retrieved data in agreement with the model predictions. Both MODIS and WRF-Chem showed a significant dust-induced reduction in the surface shortwave radiation $\left(150-300 \mathrm{~W} \mathrm{~m}^{-2}\right)$ that reached the eastern Arabian Peninsula and the Gulf waters between 01 and 03 of April. During the period of study there was no precipitation in the region and thus all aerosol deposition is attributed to dry deposition. The highest deposition rates were predicted over the eastern Arabian Peninsula and the Gulf Sea. The model predicted a maximum daily deposition in the region of $27.5 \mathrm{Tg} \mathrm{day}^{-1}$ on 2 April and an average of $11.4 \mathrm{Tg} \mathrm{day}^{-1}$ during the episode (Fig. S3). Spatially the dust deposition rate varied between $3-10 \mathrm{~g} \mathrm{~m}^{-2} \mathrm{~d}^{-1}$. The total dust that was deposited during the event was predicted to be $67.7 \mathrm{Tg}$ while approximately $30 \%$ of that was deposited over the Arabian Sea waters. As dust particles transfer minerals and nutrients into the sea the effect of such dust storms on various water activities (e.g. desalination plants, nutrient balance) needs to be thoroughly studied. Finally, the demonstrated ability of the model to predict this dust outbreak is encouraging for current efforts at forecasting major dust events in the region.

\section{ACKNOWLEDGMENTS}

The HPC (High Performance Computer cluster) resources and services used in this work were provided by the Research Computing group in Texas A\&M University at Qatar. The Research Computing is funded by the Qatar Foundation for Education, Science and Community Development (http://www.qf.org.qa). CERES data were obtained from the NASA Langley Research Center Atmospheric Science Data Center.

\section{SUPPLEMENTARY MATERIAL}

Supplementary data associated with this article can be found in the online version at http://www.aaqr.org.

\section{REFERENCES}

Anisimov, A., Tao, W., Stenchikov, G., Kalenderski, S., Prakash, P.J., Yang, Z.L. and Shi, M. (2017). Quantifying local-scale dust emission from the Arabian Red Sea coastal plain. Atmos. Chem. Phys. 17: 993-1015.

Banks, J.R., Brindley, H.E., Stenchikov, G. and Schepanski,
K. (2017). Satellite retrievals of dust aerosol over the Red Seaand the Persian Gulf (2005-2015). Atmos. Chem. Phys. 1: 3987-4003.

Beegum, N., Gherboudj, I., Chaouch, N., Temimi, M. and Ghedira, H. (2018). Simulation and analysis of synoptic scale dust storms over the Arabian Peninsula. Atmos. Res. 199: 62-81.

Bennett, C.M., McKendry, I.G., Kelly, S., Denike, K. and Koch, T. (2006). Impact of the 1998 Gobi dust event on hospital admissions in the Lower Fraser Valley, British Columbia. Sci. Total Environ. 366: 918-925.

Bennion, P., Hubbard, R., O'Hara, S., Wiggs, G., Wegerdt, J., Lewis, S., Small, I., van der Meer, J. and Upshur, R. (2007). The impact of airborne dust on respiratory health in children living in the Aral Sea region. Int. J. Epidemiol. 36: 1103-1110.

Chen, S.H. and Sun, W.Y. (2002). A one-dimensional time dependent cloud model. J. Meteorol. Soc. Jpn. 80: 99118.

Cheng, T., Chen, H., Gu, X., Yu, T., Guo, J. and Guo, H. (2012). The Inter-Comparison of MODIS, MISR and GOCART Aerosol Products against AERONET Data over China. J. Quant. Spectrosc. Radiat. Transfer 113: 2135-2145.

Collins, W.D., Rasch, P.J., Eaton, B.E., Khattatov, B.V., Lamarque, J.F. and Zender, C.S. (2001). Simulating aerosols using a chemical transport model with assimilation of satellite aerosol retrievals: Methodology for INDOEX. $J$. Geophys. Res. 106: 7313-7336.

Fast, J.D., Gustafson, W.I. Jr., Easter, R.C., Zaveri, R.A., Barnard, J.C., Chapman, E.G. and Grell, G.A. (2006). Evolution of ozone, particulates, and aerosol direct forcing in an urban area using a new fully coupled meteorology, chemistry, and aerosol model. J. Geophys. Res. 111: D21305.

Fountoukis, C., Ackermann, L., Ayoub, M.A., Gladich, I., Hoehn, R.D. and Skillern, A. (2016). Impact of atmospheric dust emission schemes on dust production and concentration over the Arabian Peninsula. Model. Earth Syst. Environ. 2: 115.

Fountoukis, C., Figgis, B., Ayoub, M.A. and Ackermann, L. (2018a). Effects of atmospheric dust deposition on solar PV energy production in a desert environment. Sol. Energy 164: 94-100.

Fountoukis, C., Pomares, L., Perez-Astudillo, D., Bachour, D. and Gladich, I. (2018b). Simulating global horizontal irradiance in the Arabian Peninsula: Sensitivity to explicit treatment of aerosols. Sol. Energy 163: 347-355.

Fountoukis, C., Ayoub, M.A., Ackermann, L., Perez-Astudillo, D., Bachour, D., Gladich, I. and Hoehn, R. D. (2018c). Vertical ozone concentration profiles in the Arabian Gulf region during summer and winter: Sensitivity of WRFChem to planetary boundary layer schemes. Aerosol Air Qual. Res. 18: 1183-1197.

Geiger, H., Barnes, I., Bejan, I., Benter, T. and Spittler, M. (2003). The tropospheric degradation of isoprene: An updated module for the regional atmospheric chemistry mechanism. Atmos. Environ. 37: 1503-1519.

Ginoux, P., Chin, M., Tegen, I., Prospero, J.M., Holben, B., 
Dubovik, O. and Lin, S.J. (2001). Sources and distributions of dust aerosols simulated with the GOCART model. $J$. Geophys. Res. 106: 20255-20273.

Goudie, A.S. and Middleton, N.J. (2006). Desert dust in the global system. Springer, $287 \mathrm{pp}$.

Grell, G.A. and Devenyi, D. (2002). A generalized approach to parameterizing convection combining ensemble and data assimilation techniques. Geophys. Res. Lett. 29: 1693.

Holben, B.N., Eck, T.F., Slutsker, I., Tanré, D., Buis, J.P., Stezer, A., Vermote, E., Reagan, Y., Kaufman, U.J., Nakajima, T., Lavenu, F., Jankowiak, I. and Smirnov, A. (1998). AERONET-A federated instrument network and data archive for aerosol characterization. Remote Sens. Environ. 66: 1-16.

Hong, S., Noh, Y. and Dudhia J. (2006). A new vertical diffusion package with an explicit treatment of entrainment processes. Mon. Weather Rev. 134: 2318 2341.

Hsu, N.C., Tsay, S.C., King, M.D. and Herman, J.R. (2004). Aerosol properties over bright-reflecting source regions. IEEE Trans. Geosci. Remote Sens. 42: 557-569.

Iacono, M.J., Delamere, J.S., Mlawer, E.J., Shephard, M.W., Clough, S.A. and Collins, W.D. (2008). Radiative forcing by long-lived greenhouse gases: calculations with the AER radiative transfer models. J. Geophys. Res. 133: D13103.

Johnson, M.S., Meskhidze, N., Kiliyanpilakkil, V.P. and Gasso, S. (2011). Understanding the transport of Patagonian dust and its influence on marine biological activity in the South Atlantic Ocean. Atmos. Chem. Phys. 11: 2487-2502.

Kalenderski S., Stenchikov, G. and Zhao, C. (2013). Modeling a typical winter-time dust event over the Arabian Peninsula and the Red Sea. Atmos. Chem. Phys. 13: 1999-2014.

Kato, S., Loeb, N.G., Rose, F.G., Doelling, D.R., Rutan, D.A., Caldwell, T.E., Yu, L. and Weller, R.A. (2012). Surface irradiances consistent with CERES-derived topof-atmosphere shortwave and longwave irradiances. $J$. Clim. 26: 2719-2740.

Kaufman, Y., Tanre, D., Remer, L., Vermote, E., Chu, A. and Hol-ben, B. (1997). Operational remote sensing of tropospheric aerosol overland from EOS moderate resolution imaging spectroradiometer, J. Geophys. Res. 102: $17051-17067$.

Kok, J.F. (2011). A scaling theory for the size distribution of emitted dust aerosols suggests climate models underestimate the size of the global dust cycle. Proc. Natl. Acad. Sci. U.S.A. 108: 1016-1021.

Kontos, S., Liora, N., Giannaros, C., Kakosimos, K., Poupkou, A. and Melas, D. (2018). Modeling natural dust emissions in the central Middle East: Parameterizations and sensitivity. Atmos. Environ. 190: 294-307.

Laurent, B., Marticorena, B., Bergametti, G., Léon, J. and Mahowald, N. (2008). Modeling mineral dust emissions from the Sahara Desert using new surface properties and soil database. J. Geophys. Res. 113: D14218.

Laurent, B., Tegen, I., Heinold, B., Schepanski, K.,
Weinzierl, B. and Esselborn, M. (2010). A model study of Saharan dust emissions and distributions during the SAMUM-1 campaign. J. Geophys. Res. 115: D21210.

Levy, R.C., Mattoo, S., Munchak, L.A., Remer, L.A., Sayer, A.M., Patadia, F. and Hsu, N.C. (2013). The Collection 6 MODIS aerosol products over land and ocean. Atmos. Meas. Tech. 6: 2989-3034.

Li, X., Wagner, F., Peng, W., Yang, J. and Mauzerall, D.L. (2017). Reduction of solar photovoltaic resources due to air pollution in China. PNAS 114: 11867-11872.

Marticorena, B. and Bergametti, G. (1995). Modeling the atmospheric dust cycle. 1. Design of a soil-derived dust emission scheme. J. Geophys. Res. 100: 16415-16430.

Mlawer, E.J., Taubman, S.J., Brown, P.D., Iacono, M.J. and Clough, S.A. (1997). Radiative transfer for inhomogeneous atmospheres: RRTM, a validated correlated-k model for the longwave. J. Geophys. Res. 102: 16663-16682.

Morman, S.A. and Plumlee, G. S. (2014). Dust and human health. In Mineral dust: A key player in the Earth system, Knippertz, P. and Stuut, J.B.W. (Eds.), Springer Netherlands, Dordrecht, pp. 385-409.

Pease, P.P., Tchakerian, V.P. and Tindale, N.W. (1998). Aerosols over the Arabian Sea: Geochemistry and source areas for aeolian desert dust. J. Arid. Environ. 39: 477496.

Prakash, P.J., Stenchikov, G., Kalenderski, S., Osipov, S. and Bangalath, H. (2015). The impact of dust storms on the Arabian Peninsula and the Red Sea. Atmos. Chem. Phys. 15:199-222.

Prospero, J.M., Ginoux, P., Torres, O., Nicholson, S.E. and Gill, T.E. (2002). Environmental characterization of global sources of atmospheric soil dust identified with the Nimbus 7 Total Ozone Mapping Spectrometer (TOMS) absorbing aerosol product. Rev. Geophys. 40: 1002.

Remer, L.A., Kleidman, R.G., Levy, R.C., Kaufman, Y.J., Tanre, D., Mattoo, S., Martins, J. V., Ichoku, C., Koren, I., Yu, H. and Holben, B.N. (2008). Global aerosol climatology from the MODIS satellite sensors. $J$. Geophys. Res. 113: 1-18.

Rezazadeh, M., Irannejad, P. and Shao, Y. (2013). Climatology of the Middle East dust events. Aeolian Res. 10: 103-109.

Roshan, D., Koc, M., Isaifan, R., Shahid, M.Z. and Fountoukis, C. (2019). Aerosol optical thickness over large urban environments of the Arabian Peninsula Speciation, variability and distributions. Atmosphere 10: 228.

Ruiz-Arias, J.A., Dudhia, J., Gueymard, C.A. and PozoVazquez, D. (2013). Assessment of the Level-3 MODIS daily aerosol optical depth in thecontext of surface solar radiation and numerical weather modeling. Atmos. Chem. Phys. 13: 675-692.

Rutan, D.A., Kato, S., Doelling, D.R., Rose, F.G., Nguyen, L.T., Caldwell, T.E. and Loeb, N.G. (2015). CERES synoptic product: Methodology and validation of surface radiant flux. J. Atmos. Oceanic Technol. 32: 1121-1143.

Saraga, D., Maggos, T., Sadoun, E., Fthenou, E., Hassan, H., Tsiouri, V., Karavoltsos, S., Sakellari, A., Vasilakos, C. and Kakosimos, K. (2017). Chemical characterization of 
indoor and outdoor particulate matter $\left(\mathrm{PM}_{2.5}, \mathrm{PM}_{10}\right)$ in Doha, Qatar. Aerosol Air Qual. Res. 17: 1156-1168.

Shalaby, A., Rappenglueck, B. and Eltahir, E.A.B. (2015). The climatology of dust aerosol over the arabian peninsula Atmos. Chem. Phys. Discuss. 15: 1523-1571.

Shao, Y., Wyrwoll, K.H., Chappell, A., Huang, J., Lin, Z., McTainsh, G.H. and Yoon, S. (2011). Dust cycle: An emerging core theme in Earth system science. Aeolian Res. 2: 181-204.

Stockwell, W.R, Kirchner, F., Kuhn, M. and Seefeld, S. (1997). A new mechanism for regional atmospheric chemistry modeling. J. Geophys. Res. 102: 25847-25879.

Su, L. and Fung, J.C.H. (2015). Sensitivities of WRF-Chem to dust emission schemes and land surface properties in simulating dust cycles during springtime over East Asia. J. Geophys. Res. 120: 11215-11230.

Tanre, D., Kaufman, Y., Herman, M. and Mattoo, S. (1997). Remote sensing of aerosol properties over oceans using the MODIS/EOS spectral radiances. J. Geophys. Res. 102: 116971-16988.

Tsiouri, V., Kakosimos, K.E. and Kumar, P. (2015).
Concentrations, sources and exposure risks associated with particulate matter in the Middle East Area-A review. Air Qual. Atmos. Health 8:67-80.

U.S. EPA (United States Environmental Protection Agency) (2000). EPA-QA/G-9. https://www.epa.gov/sites/product ion/files/2015-06/documents/g9-final.pdf.

Zender, C.S., Tegen, I. and Miller, R. (2004). Quantifying mineral dust mass budgets: Terminology, constraints, and current estimates. Eos Trans. AGU 85: 509-512.

Zhao, C, Liu, X, Leung, L.R., Johnson, B., McFarlane, S.A., Gustafson, W.I. Jr., Fast, J.D. and Easter, R. (2010). The spatial distribution of mineral dust and its shortwave radiative forcing over North Africa: Modeling sensitivities to dust emissions and aerosol size treatments. Atmos. Chem. Phys. 10: 8821-8838.

Received for review, April 30, 2019 Revised, August 26, 2019 Accepted, December 4, 2019 